\title{
Coenzyme Q10 Deficiency
}

National Cancer Institute

\section{Source}

National Cancer Institute. Coenzyme Q10 Deficiency. NCI Thesaurus. Code C142083.

A genetically heterogeneous condition, typically inherited in an autosomal recessive fashion, characterized by coenzyme Q10 deficiency. 